\title{
アゾベンゼン修飾キラル固定相を用いるマイクロ液体クロマト グラフィーにおける光学異性体の光照射による溶出順序制御
}

\author{
猪狩 民行 ${ }^{1}$ ，中釜 達朗 ${ }^{\circledR 1}$ ，内山 一美 ${ }^{1}$ ，保母 敏行 ${ }^{1}$
}

\author{
Control of the elution order of enantiomers by light irradiation \\ using azobenzene-modified chiral stationary phases \\ in micro liquid chromatography
}

Tamiyuki IGARI ${ }^{1}$, Tatsuro NAKAgAma ${ }^{1}$, Katsumi UchiYAma ${ }^{1}$ and Toshiyuki Hobo ${ }^{1}$

${ }^{1}$ Development of Applied Chemistry, Graduated School of Engineering, Tokyo Metropolitan University, 1-1, Minamiosawa, Hachioji, Tokyo 192 - 0397

(Received 18 August 2003, Accepted 25 August 2003)

\begin{abstract}
In micro liquid chromatography, a method for the reversible control of the elution order of enantiomers by light irradiation was developed. Two photo-responsive chiral stationary phases $(\operatorname{CSP}(1)$ and $\operatorname{CSP}(2))$ with an azobenzene moiety were prepared using D- and L-valine, respectively. The prepared stationary phases were continuously packed into a UV-permeable polymercoated fused-silica capillary tubing $(100 \mu \mathrm{m}$, i.d.) with $20 \mathrm{~cm}$ of length, respectively, and used as a micro column. When 3,5-dinitrobenzoyl-D,L-leucine isopropyl ester and 3,5-dinitrobenzoyl$\mathrm{D}, \mathrm{L}-$ alanine methyl ester were used as test samples, the samples were eluted in the order D-form and L-form, after UV light was irradiated to only the part of $\operatorname{CSP}(1)$ in the column. Continuously, when UV light was irradiated to the part of CSP(2) after visible light was irradiated to the CSP (1), the elution order became L-form and D-form. It could be seen that a reversible change in the retention order was caused by the reduction of the enantio-selectivity of the stationary phase by UV light irradiation.
\end{abstract}

Keywords : enantiomer separation; HPLC micro column; control of elution order ; photoresponsive stationary phase.

\section{1 緒言}

近年, 生体内における光学活性生理活性物質のラセミ化 あるいは $\mathrm{D}-ア ミ ノ$ 酸の役割 $^{1)}$ な゙が明らかにされてきてい る. また, 副作用の問題などから光学活性医薬品の光学純 度測定 ${ }^{2}$ が重要になっており, 光学異性体分離分析の重要 性はますます高まっている，光学純度測定の場合には片方 の光学異性体が極微少量であることが多く, 先に溶出させ たほうが定量に有利な場合がある ${ }^{3)}$. 液体クロマトグラフ イー（LC）においては充填刻のキラリティーを変えるこ とが多く, キラリティーだけが異なるカラムも市販されて

${ }^{1}$ 東京都立大学大学院工学研究科: 192-0397 東京都八王子市南 大沢 $1-1$
いる.

一方, 分離系のダウンサイジングが急速に進んでいる. チップ化された装置や電気浸透流を利用した分離系では流 路系と分離系が一体化したものが多く, 分離部を変更する ことは容易ではない. キャピラリーLCにおいてもカラム 接続部における試料ゾーンの拡散が懸念される.

著者らは，アゾベンゼン部位を固定相に導入し，光照射 により分離挙動を制御する試みを行ってきている(4) 6). 本 研究では, 光照射により光学異性体の溶出順序を制御する ことを検討した．概念図を Fig. 1に示す．同一カラム内 に分子構造が同じでキラリティーだけが異なる光応答性固 定相 $\{$ Fig. 1， CSP(1) 及び CSP(2)\}をそれぞれ存在させ る.この状態では，それぞれの CSP に由来するキラル認 
識能が相殺されて，カラムとしてはキラル認識できないよ うにする. CSP (1) 及び CSP(2) のキラル認識能が光照射 により変化すると, どちらかの CSP のキラル認識能が反 映された溶出順序となる，本研究では，キラルセレクター として光学純度が高く, かつ双方の光学異性体が比較的安

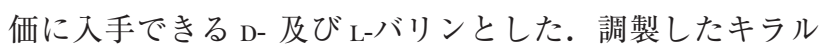
固定相はアミノ酸アミド型7である。この固定相について は，アルキルスペーサーの長さによりキラル分離能が異な ることが報告されている ゾベンゼン部位を導入（Fig. 2）することで, 光照射によ り固定相のキラル認識能を可逆的に変えることができると 考えた。

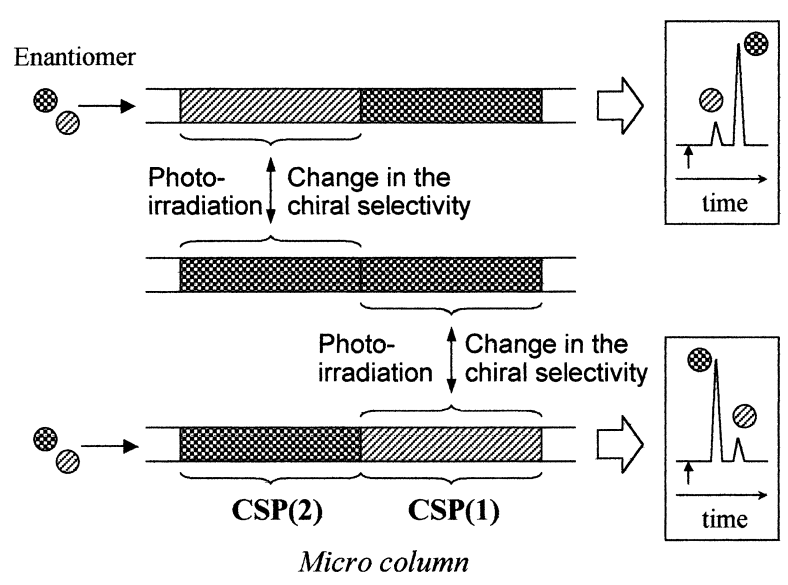

Fig. 1 Concept of the change in the elution order of enantiomers by photo-irradiation using photo- responsive chiral stationary phases
2 実験

\section{$2 \cdot 1$ 光応答性キラル固定相及びマイクロカラムの調製}

固定相の調製は以下のように行った. まず， $n$-ヘキシル アミン（東京化成製）と tert-ブチルオキシカルボニル (Boc)-D-バリン (ペプチド研究所製) を1-\{3-(ジメチルア ミノ)プロピル\}-3-エチルカルボジイミド塩酸塩（EDC$\mathrm{HCl}$ ）(東京化成製）及び 1-ヒドロキシベンゾトリアゾール (HOBt) (同仁化学製) を用いてジクロロメタン中, $0{ }^{\circ} \mathrm{C}$ で カップリングした。次にトリフルオロ酢酸中で Boc 基を 除去した後, 再び EDC-HCl 及び HOBt を用いてジメチル アセトアミド中, $0{ }^{\circ} \mathrm{C}$ でアゾベンゼン $-4,4$ '-ジカルボン酸 (東京化成製) とモル比 $1: 1$ で反応させた化合物を合成し た. 最後に EDC-HCl 及び $N$-ヒドロキシコハク酸イミド $(\mathrm{HONSu})$ (和光純薬製) を用いてジメチルアセトアミド 中, $0{ }^{\circ} \mathrm{C}$ でアミノプロピルシリカゲル (APS) (Deverosil $\mathrm{NH}_{2}$ 100-5, 平均粒子径 $5 \mu \mathrm{m}$, 細孔径 $100 \AA$, 比表面積 $350 \mathrm{~m}^{2} / \mathrm{g}$, 野村化学製) と反応させ, 光応答性キラル固 定相 CSP (1) を得た。キラリティーの異なる固定相 $\mathrm{CSP}(2)$ は, Boc-D-バリンの代わりに Boc-L-バリン（ペプチ ド研究所製）を用いることにより調製した. CSP (1) 及び $\operatorname{CSP}(2)$ の元素分析における炭素含有量は共に $6.3 \%$ であ った. APS の炭素含有量が $2.9 \%$ であったことから, 既報 ${ }^{9)}$ と同様の方法でキラルセレクターの平均固定化密度を求め た結果, $\operatorname{CSP}(1)$ 及び $\operatorname{CSP}(2)$ 共に 0.18 groups $/ \mathrm{nm}^{2}$ (1 $\mathrm{nm}^{2}$ 当たり 0.18 個のキラルセレクターが存在している) と推算された。

調製した固定相は，末端に水ガラスを焼結させて作製し たフリットを有する光透過性ポリマー被覆石英キャピラリ

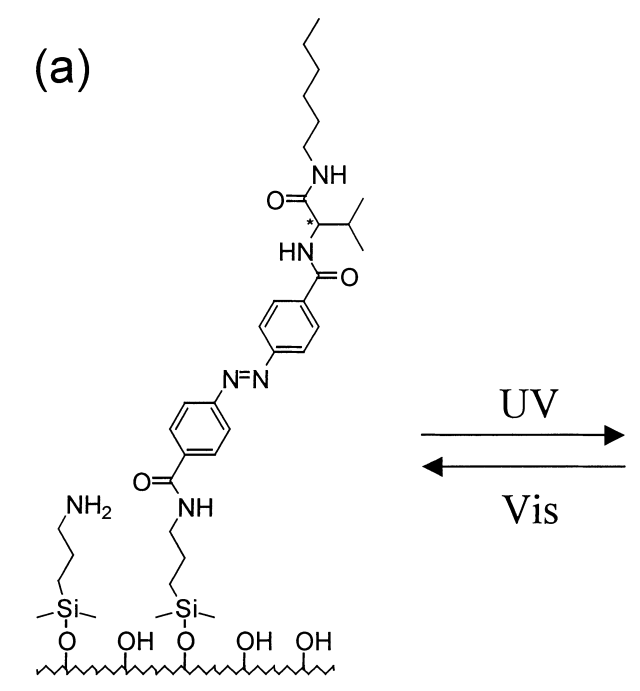

(b)

Silica gel

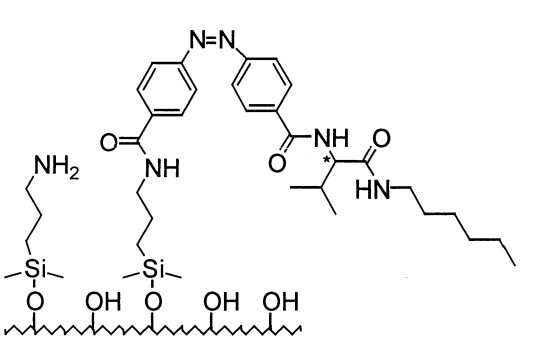

Fig. 2 Photo-responsive chiral stationary phase used in this study, the trans-form (1) and the cis-form (2) 


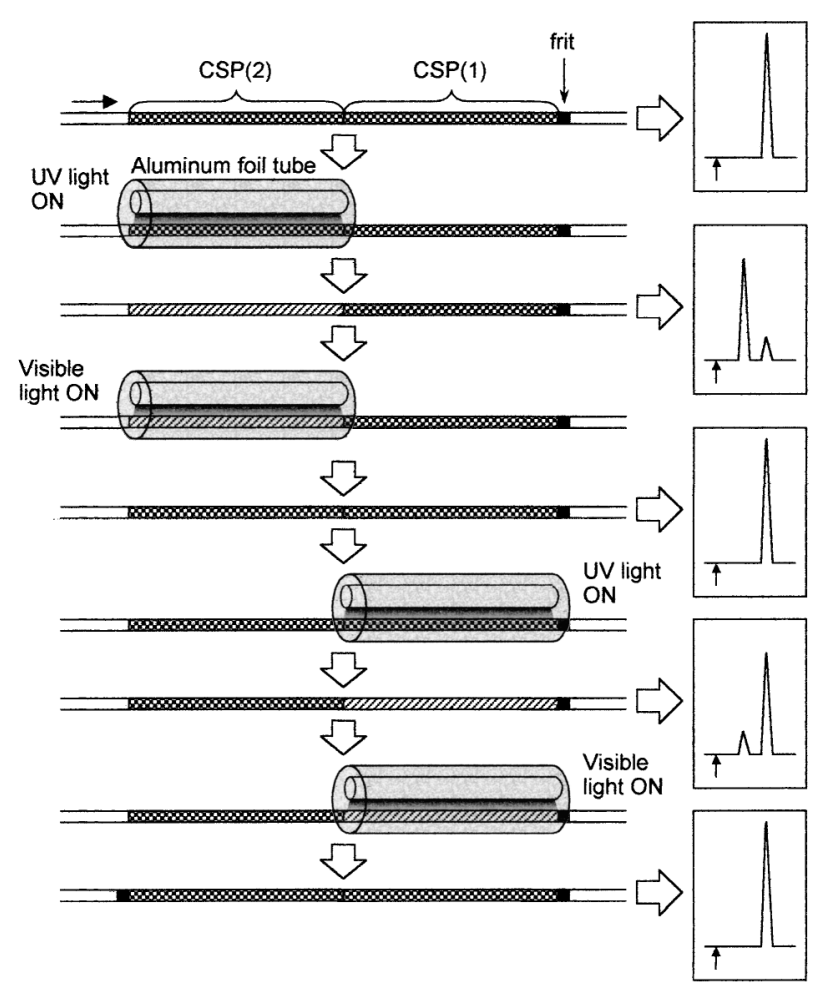

Fig. 3 Experimental scheme of this study

All HPLC measurements were performed in the dark.

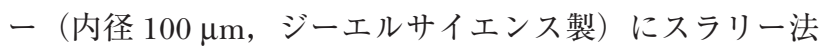
により充填した。まず， CSP $(1)$ を $20 \mathrm{~cm}$ 充填した後，続 いて $\operatorname{CSP}(2)$ を $20 \mathrm{~cm}$ 充填した.

\section{$2 \cdot 2$ 分析装置及び試料}

調製したマイクロカラムの分離能及び光応答性は高速液 体クロマトグラフィー（HPLC）用ポンプ（L6000, 日立 製)，インジェクター (7520，レオダイン製)，カラム恒 温槽 (3521C，七ンシュー科学製）及びキャピラリー電気 泳動用紫外可視吸光光度検出器 (CE-971UV, 日本分光製) で構成される HPLC装置により評価した。検出器からの 信号はインテグレーター（C-R7A，島津製）で処理した. 紫外あるいは可視光源にはブラックライト（FL6BLB，6 $\mathrm{W}$ ，東芝ライテック製）あるいは蛍光管（FL6N，6 W, 東芝ライテック製）を 1 本ずつ使用した。光を照射する 場合, 光源は恒温槽内でマイクロカラムと並列に設置し, カラム背後に光を照射するために, その周囲をアルミはく で作製した筒で覆った (Fig. 3). 光源とカラムとの距離 は $1 \mathrm{~cm}$ とした。

試料注入量は $0.2 \mu \mathrm{l}$, 恒温槽温度は $15^{\circ} \mathrm{C}$, 試料の検出波 長は $254 \mathrm{~nm}$ とした。本研究において調製した固定相 （Fig. 2）は，アミノ酸をキラル認識部位とし，アミノ酸 の $\mathrm{N}$ 末端に芳香環を有するいわゆるアミノ酸アミド型キ ラル固定相である。アミノ酸アミド型キラル固定相におい
ては，順相系 HPLC において 3,5-ジニトロベンゾイル基の ような芳香環を有するアミノ酸エステル誘導体に対して比 較的分離能が高いことが知られている ${ }^{10)}$. そこで本研究で は，保持の光応答性が確認しやすい試料として，3,5-ジニ トロベンゾイル-D,L-アラニン-メチルエステル（DNB-D,LAla-ME）及び 3,5-ジニトロベンゾイル-D,L-ロイシン-イソプ ロピルエステル（DNB-D,L-Leu-IPE）を用いた。移動相に は，1\% 2-プロパノール及び 10\% ジクロロメタンを含む ヘキサン溶液を用いた。なお，本研究で使用したポンプは 極微流量送液（10 $\mu \mathrm{l} / \mathrm{min}$ 以下）が困難であったため，定 圧送液 $\left(300 \mathrm{kgf} / \mathrm{cm}^{2}\right)$ とした。 ホールドアップ時間 $\left(t_{0}\right)$ の測定には 1,3,5-トリ-tert-ブチルベンゼンを用いた.

移動相を送液した状態で一定時間紫外あるいは可視光照 射を行った後，暗下にてHPLC 测定を行った（Fig. 3). それぞれの光照射は保持時間の変化が平衡状態になるまで 続けた。実際に保持の変化が平衡に達するまでの光照射時 間は紫外，可視光照射とも約 6 時間であった。

\section{3 結果及び考察}

スラリー法によって CSP(1)，CSP(2) をそれぞれ $20 \mathrm{~cm}$ ずつ充填したマイクロカラムを用いて HPLC 測定を行っ た。試料として DNB-D,L-Leu-IPE の移動相溶液（D 体 : L 体 $=1: 4 ＼mathrm{~ を 用 い た と き ， ク ロ マ ト ク ゙ ラ ム て ゙ は ~} 1$ 本のピ ークとして検出された。次に, $\operatorname{CSP}(2)$ を充填した部分だ けに紫外光照射を行うと, 試料の D 体の溶出時間はほと んど変わらずに L 体の溶出時間だけが早くなり \{Fig. 4 (a) $\}, 2$ 本のピークとして検出された $\left\{t_{0}=15.3 \mathrm{~min}\right.$, 分 離係数 $(\alpha)=1.24\}$. CSP $(2)$ だけに可視光照射を行うと

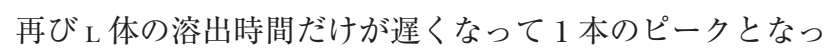
た。続いて， CSP (1) を充填した部分にだけ紫外光照射を 行ったところ，D体のピークが $\mathrm{L}$ 体ピークの立ち上がり部 分の肩として出現した。 D 体のピークを確認するために試 料溶液中の $\mathrm{D}$ 体と $\mathrm{L}$ 体の混合比を $1: 2$ としたところ, D 体のピークが明確になった $\{$ Fig. $4(\mathrm{~b})\}$ 。このときの $\alpha$ 值は 1.16 と計算された。その後, $\operatorname{CSP}(1)$ にだけ可視光照 射を行ったところ， D 体の溶出時間だけが遅くなって 1 本 のピークとなった。 Fig. 5 は DNB-Ala-ME 溶液（D 体 : L 体 = 1：2）を試料として同様な光照射実験を行った結果 である. DNB-Ala-ME と同様, 光照射により溶出順序の逆 転が確認された。このときの $\alpha$ 值はそれぞれ 1.05 Fig. $5(\mathrm{a})\}$ 及び $1.04\{$ Fig. 5(b)\} と計算された.

アミノ酸アミド型キラル固定相を用いた順相系 HPLC の場合，固定相のアルキルスペーサー鎖長を短くすると残 存シラノール基の影響などによりキラル認識能が低下する との報告がある ${ }^{8)}$. 実験結果（Fig. 4 及び Fig. 5）から， Fig. 2 の CSP はトランス-シス光異性化により，スペーサ 一鎖長が短くなるのと同様な効果，すなわち，残存シラノ 


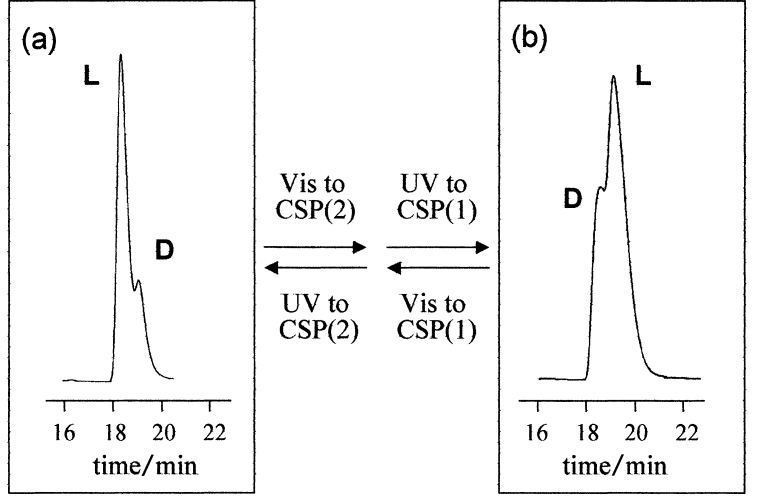

Fig. 4 Change in the elution order of DNB-D,L-LeuIPE by photo-irradiation using the micro column in HPLC

The molar ratios of the enantiomer (D : L) were $1: 4$ (a) and 1:2 (b), respectively. HPLC conditions are described in the text.

ール基などの影響によりキラル分離能が低下するものと考 えられる。

$$
4 \text { 結 論 }
$$

キラリティーだけが異なる光応答性キラル固定相をそれ ぞれ充填したマイクロカラムを用いて，光照射により光学 異性体の溶出順序を制御することに成功した。今後, 試料 導入量を少なくする，固定相の分子構造を最適化する， あ るいは光照射方法を改善することなどにより，より明確な 光応答性が発現できると考える.また, 問題点としてカラ 厶圧損失が大きいことが挙げられる. 固定相の固定化担体 として，より圧損失の少ないモノリスシリカ ${ }^{\left.11{ }^{12}\right)}$ の利用を 現在検討中である.

本研究は, 文部科学省科学研究費補助金（基盤研究 $(\mathrm{C})$, 「才 ンサイトキラルスイッチング微小カラムの開発」により遂行され たものである。

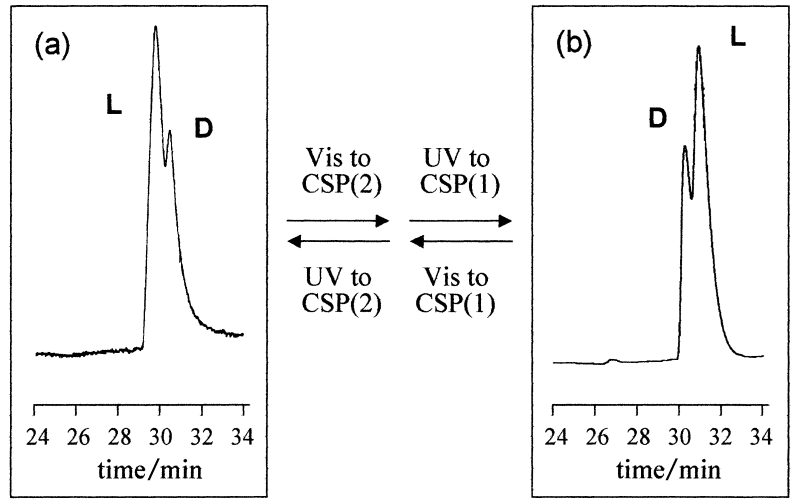

Fig. 5 Change in the elution order of DNB-D,L-AlaME by photo-irradiation using the micro column in HPLC

The molar ratio of the enantiomer (D : L) was $1: 2$. HPLC conditions are described in the text.

\section{文献}

1) K. Imai, T. Fukushima, T. Santa, H. Homma, K. Hamase, K. Sakai, M. Kato: Biomed. Chromatogr., 10, 303 (1996).

2) 医薬審第 496 号厚生省医薬安全局審査管理課長通 知, “非臨床薬物動態試験ガイドラインについて” (1998.6.26).

3) 二村典行：ぶんせき (Bunseki), 1999, 456.

4) H. Matsuoka, T. nakagama, T. Hobo: J. High Resol. Chromatogr., 21, 25 (1998).

5) T. Nakagama, K. Hirasawa, K. Uchiyama, T. Hobo: Anal. Sci., 17, 119 (2001).

6) T. Nakagama, A. Yamaguchi, K. Hirasawa, K. Yoshida, K. Uchiyama, T. Hobo: Anal. Sci., 18, 49 (2002).

7) W. H. Pirkle, C. J. Weich: J. Org. Chem., 49, 138 (1984).

8) N. B.-Leyder, J.-C. Truffert, A. Tambute: J. Chromatogr., 666, 27 (1994).

9) T. Ihara, Y. Sugimoto, M. Asada, T. Nakagama, T. Hobo: J. Chromatogr. A, 694, 49 (1995).

10) K. Sato, H. Nakano, T. Hobo: J. Chromatogr. A, 666, 463 (1994).

11) Z. Chen, K. Uchiyama, T. Hobo: J. Chromatogr. A, 942, 83 (2002).

12) Z. Chen, M. Niitsuma, K. Uchiyama, T. Hobo: J. Chromatogr. A, 990, 75 (2003). 